\title{
透水性鋼矢板まわりの浸透流による 砂質土の内部浸食
}

\author{
小柿響 $1 \cdot 丸 山$ 貴広 $^{2} \cdot$ 堀越一輝 $^{2} \cdot$ 竹山智英 ${ }^{3} \cdot$ 高橋章浩 $^{2}$ \\ 1 西日本電信電話株式会社（元東京工業大学 大学院理工学研究科 土木工学専攻） \\ 2 東京工業大学 大学院理工学研究科 土木工学専攻（†152-8552 東京都目黒区大岡山二丁目12-1） \\ E-mail:maruyama.t.am@m.titech.ac.jp, horikoshi.k.aa@m.titech.ac.jp, takihiro@cv.titech.ac.jp \\ 3 神戸大学大学院工学研究科 市民工学専攻（† 657-8501 兵庫県神戸市灘区六甲台町1-1） \\ E-mail: takeyama@people.koke-u.ac.jp
}

\begin{abstract}
地震時の堤防の液状化や越流による破堤の対策として堤防基礎地盤に設置される透水性鋼矢板の透水孔 付近を対象に，浸透による内部浸食の進展過程について，実験的・数值解析的に調べた。数值解析では, 浸透流によって浸食された細粒土は間隙水に取り込まれ, 間隙流体としてふるまうと仮定し, その連続条 件から得られる間隙流体中の細粒土濃度に関する移流方程式を解いた. 本解析によって模型実験で観察さ れた透水孔付近での細粒土の流出を概ね再現することができたが，実験で発生した細粒土による目詰まり については，用いた浸食モデルでは，一旦間隙流体に取り込まれた細粒土が動水勾配低下時に再堆積する 現象を考慮していないため, 再現できなかった。
\end{abstract}

Key Words : internal erosion, seepage, permeable sheet pile

\section{1. はじめに}

地震時の堤防の液状化や越流による破堤の対策として, 鋼矢板を堤防の法肩に設置する工法が提案されている. このような鋼矢板の治水構造物一の設置は，常時や洪水 時の基礎地盤の浸透特性を変化させてしまうため，その 影響を小さくすることを目的として，十分な透水量を確 保できる透水孔が設けられた透水性鋼矢板 ${ }^{1)}$ (図-1）が 用いられることがある. しかし，透水孔付近では局所的 な浸透流が発生するため，これに起因する土の内部浸食 が懸念される.

内部浸食には様々なモードがあるが，本研究では，浸 透流により土骨格中の間隙に存在寸る細粒分の剥離・移 動現象であるsuffusionと呼ばれる現象を対象とする（以 降，内部浸食とは，この現象を指すこととする）。浸透 流による土の内部浸食が発生すると，土の体積がほとん ど変化しない場合には，細粒土の流出により土の空隙が 大きくなるため, ダムや堤防などの治水・利水構造物に おいては，水の浸透特性が変化し，止水機能の低下が懸 念される.また，このような内部浸食は，土の透水性を 変化させるだけでなく，剛性や強度も変化させることが 知られており, Ke and Takahashi ${ }^{24)} や($ 佐藤”は, 三軸試験器
内での浸食現象の再現と，その後のせん断試験によって， 内部浸食を受けた土の力学特性が変化することを示して いる.

このような要素的な試験は比較的多く行われており，
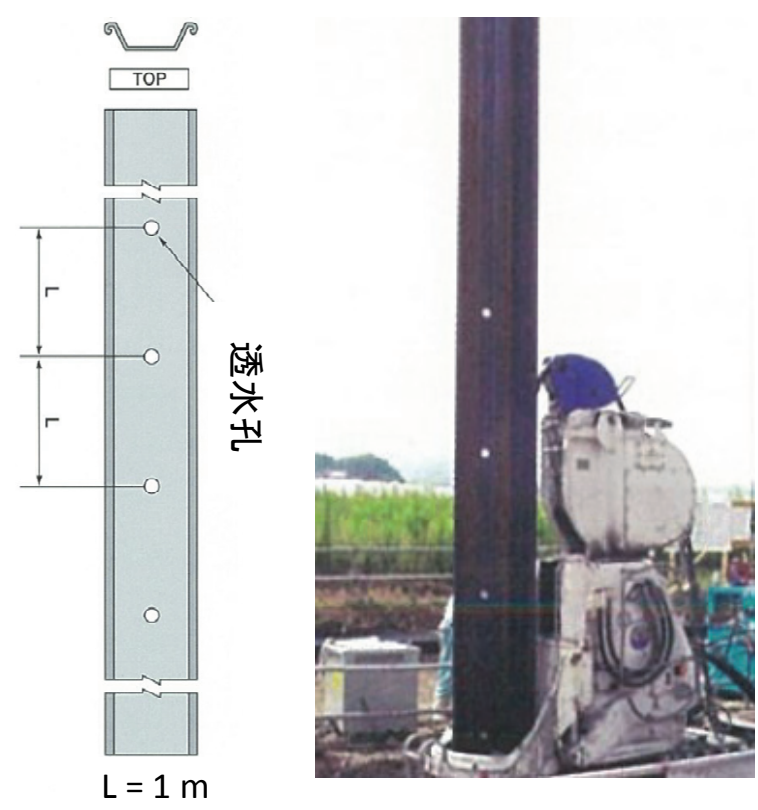

図-1 透水性鋼矢板 
特に, 内部浸食が発生する可能性のある土は, 内部不安 定な土と呼ばれ，その判別に資する主に1次元浸透実験 に基づく実験的研究は多い，一方，具体的な構造物など を対象とした研究は，解析的なものについては，Sterpi ${ }^{9}$, Cividini et $a l^{7}$ ”による動水勾配をべースにした内部浸食モ デルの定式化と地下水流れに伴う地盤沈下問題への適用, Fujisawa et $a l^{8}$ !による土粒子の剥離に伴うパイピングの時 間発達の計算, Uzuoka et al. ${ }^{9}$ による天然ダムの細粒分含 有率分布の時間変化の計算などがある. しかしながら， 浸透流による地盤（構造物）内の細粒土の時間・空間的 変化に関する現地調査もしくは模型実験の事例は少ない. Radzicki and Bonelli ${ }^{10}$ は, 盛土内の温度分布の計測により 間接的に細粒土の移動やパイピングの検知を試みている. Horikoshi and Takahashi ${ }^{11}$ は，小型盛士模型に対寸る浸透実 験を行い，盛土内の細粒土分布の時空間的変化を詳細に 調べている.

本研究では，堤防基礎地盤に設置した透水性鋼矢板の 透水孔付近の局所浸透流が引き起こす内部浸食の進展過 程と浸食の程度を明らかにすることを目的として，模型 実験と数值解析を実施した. 模型実験では, 矢板の透水 孔付近の地盤をモデル化し，これに浸透流を与えること によって, 土の浸食過程を観察した. 数值解析では, 浸 透流によって浸食された細粒土は間隙水に取り込まれ， 間隙流体としてふるまうと仮定し，その連続条件から得 られる間陌流体中の細粒土濃度に関寸る移流方程式を解 くことによって, 土の浸食過程を計算し, 模型実験との 比較を行った.

\section{2. 実験・数値解析の概要}

\section{(1) 対象とするモデル堤防}

図-2に示寸ような，液状化対策として透水性鋼矢板が 法肩に設置された堤防の基礎地盤を今回の検討対象とし た. 基礎地盤は液状化層（層厚 $h=5 \mathrm{~m}$, 飽和透水係数 $k=$ $\left.1.7 \times 10^{-3} \mathrm{~m} / \mathrm{s}\right)$ と支持層（ $h=5 \mathrm{~m}, k=1.0 \times 10^{4} \mathrm{~m} / \mathrm{s} ）$ で構成さ れており, 矢板は $2.5 \mathrm{~m}$ 支持層に根入れされているとし た. また，洪水時を想定して堤内外水位差は $4 \mathrm{~m}$ とた。 透水性を確保する透水孔については, 実物を参考に, 矢板には液状化層内において $1 \mathrm{~m}$ 毎に直径 $80 \mathrm{~mm} の 5 つ の$ 透水孔が存在するとした．ただし解析では，3次元性に ついては考慮せず，奥行き方向に連続して開口している と仮定して2次元で実施した. このような仮定は, 矢板 の有効幅が $600 \mathrm{~mm}$ である（連結すると透水孔の水平間 隔が600 mmとなる）ことを考えると，開口面積は $600 \times$ $80 /\left(\pi 80^{2} / 4\right)=9.5$ 倍となるため, 開口部付近の局所流を 過小評価することになる。しかし，後述する模型実験は 地盤内の細粒土の移動の観察を容易にするため 2 次元模 型で行うことにしたため，これに合せて2次元での解析

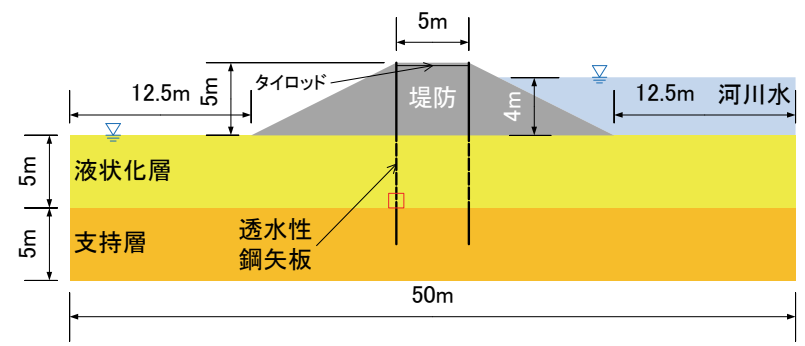

図-2 透水性鋼矢板の設置された堤防と基礎地盤

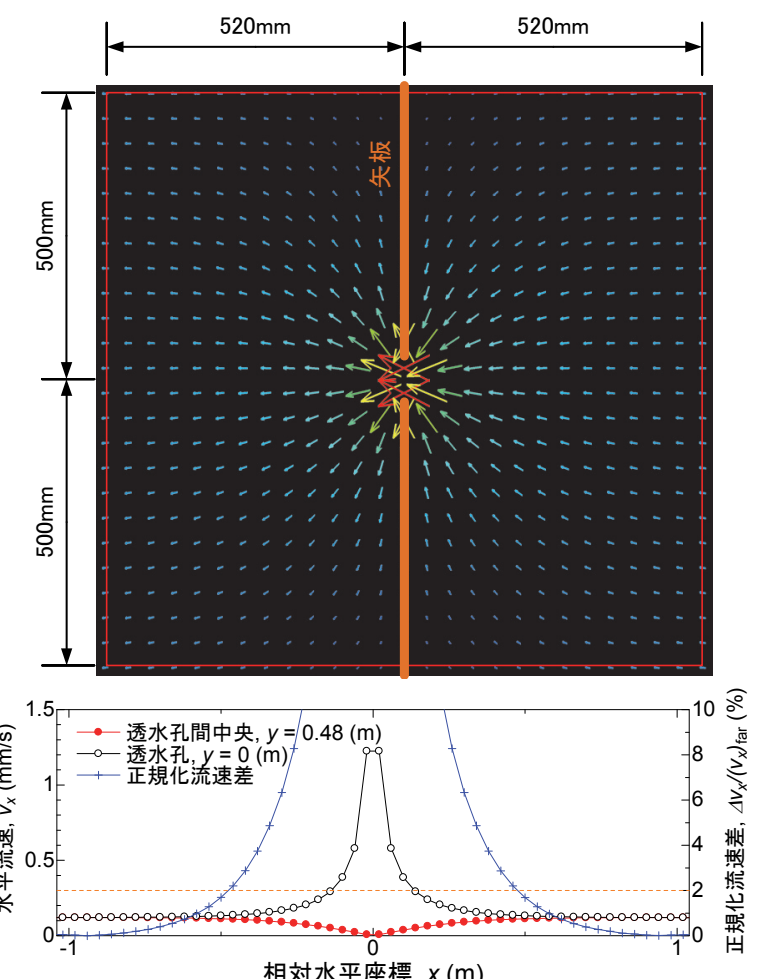

図-3 透水孔まわりの流速分布

を実施した。

図-2の堤防底面，支持層底面，両側方境界（法尻から $12.5 \mathrm{~m})$ を不透水境界として, 基礎地盤を対象に飽和浸 透流解析を実施した. 図-3に得られた透水孔周りの流速 分布を示す．上のベクトル図は, 図-2で赤囲みした領域 の流速の空間分布を示しており, 局所流が発生している 箇所が透水孔付近である. なお, 図化にあたっては, 要 素で得られている流速を節点にマッピングしているため, 矢板線上の節点では異なる方向のベクトルが2つ描かれ ているが，実際の当該点における流速は，これらを合成 したものに相当する. また, 下の図は, 透水孔高さ, 並 びに，上の透水孔との中間高さ付近の水平速度と，これ らの差を水平流速が一様となっている箇所での流速で正 規化した流速差の水平方向分布を示している.

対象地盤が左右対称なことと, 堤防下の浸透流は矢板 近傍を除きほぼ水平であることから, どの透水孔に着目 しても, 結果はほぼ同じである. 透水孔矢板付近の水の 流れを調べた結果, 図に示寸ように透水孔から上下流方 向に520 mm離れると, 透水孔高さと透水孔中間高さに 
おける流速の差が $2 \%$ 以上ななり，浸透流がほぼ水平定 常流となることが確認された，なお，透水孔付近での最 大流速は $1.23 \mathrm{~mm} / \mathrm{s}$ であり, 矢板がない場合の堤防下の平 均流速 $(0.134 \mathrm{~mm} / \mathrm{s})$ と比べると約10倍であった。この ような数值解析結果を踏まえて, 以降の模型実験・数值 解析の対象領域を決定した.

\section{(2) 模型実験の概要}

前小節に示した対象領域の1/4スケールの模型（図-4） を作製して実験を行った．なお，奥行きは440 mmであ る. 地盤材料には，浸食されやすい土として，比較的粒 度の揃った珪砂 3 号（平均粒径 $D_{50}=1.25 \mathrm{~mm}$ ) および珪砂 8 号 $\left(D_{50}=0.076 \mathrm{~mm}\right)$ の混合砂 $\left(k=1.7 \times 10^{-3} \mathrm{~m} / \mathrm{s}\right.$, 初期間隙 率 $n=0.407$, 乾燥密度 $\left.\rho_{\mathrm{d}}=1.56 \mathrm{Mg} / \mathrm{m}^{3}\right)$ を用いた. 珪砂 8 号 は土質分類からすると細粒土ではないが，本研究では細 粒土として扱い，その初期含有率は $15 \%$ であ（図-5参 照）。なお，試料の浸透に対する不安定性（内部浸食の しや寸さ）を粒度分布から判定する方法は多数提案され ており，例えば, Kenney and Lau' ${ }^{12)}$, Li and Fannin ${ }^{13)}$, Wan and Fell ${ }^{14}$, Chang and Zhang ${ }^{15}$ らの判定法に従うと, 今回用 いた試料は，これらのどれを使っても不安定と判断され る.

モデル化においては，本来であれば実際に即して，矢 板を鉛直に設置し，水平方向に浸透流を与えるべきであ るが，浸透・浸食による地盤の若干のゆるみが水みちを 形成してしまう恐れがあることから，これを最小限に抑 えるため, アクリル製土槽内に模型地盤を作製し，矢板 を模したアクリル板を模型地盤中央に水平に設置した上 で（模型矢板が浸透に伴う土の堆積変化に追随できるよ う, 容器と模型矢板の間は止水するものの接合はしてい ない），模型地盤の上下端に水頭差を与え，鉛直方向に 浸透流を付与寸ることにより透水性矢板まわりの地盤を 模擬した（透水孔の開口幅は $20 \mathrm{~mm}$ ）。 上向き浸透流を 18時間模型に付与することにより，透水孔を模した開口 部周りに内部浸食を発生させ，細粒土の移動や流量の変 化を観察した. 与える対象領域の平均動水勾配は, 前小 節の事前解析結果から 0.303 とし, 上下端の水頭差を 79 mmに設定した.

\section{(3) 数值解析の概要}

前小節に示した模型実験を対象に数值解析を実施した. 本解析では，浸透流によって浸食された細粒土は間隙水 に取り込まれ，間隙流体としてふるまうと仮定し，その 連続条件から得られる下記の間隙流体中の細粒土濃度 $\rho_{e}$ に関する移流方程式を解いた。

$$
\frac{\partial \rho_{e}}{\partial t}+\frac{\partial\left(\rho_{e} v_{i}\right)}{\partial x_{i}}-Q_{e}=0
$$

ここで, $v_{i}=x_{i}$ 方向のダルシー流速, $Q_{e}=$ 間隙流体に取り

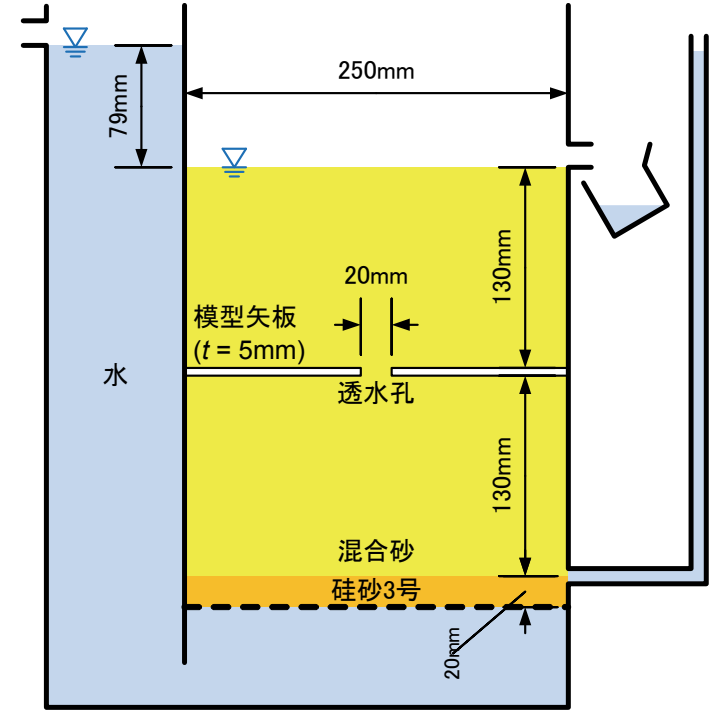

図-4 模型地盤の概要

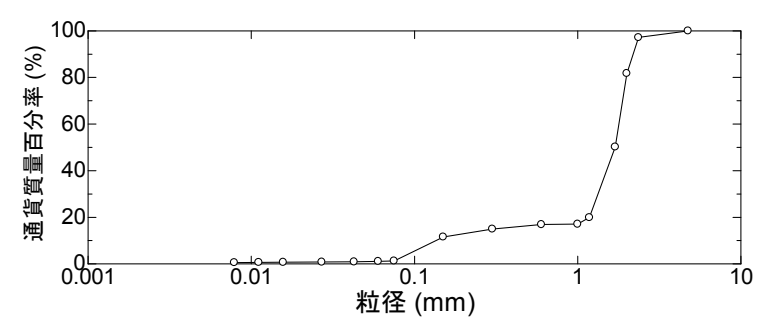

図-5 用いた試料の粒度分布

込まれた単位体積あたりの細粒土の質量の変化（増加速 度）である. 時空間離散化は, 計算の安定化のため Taylor-Galerkin有限要素法 ${ }^{16}$ を用いた。 $\left.\rho_{e}\right|_{n+1}$ の時刻 $t=t_{n}$ まわりのテーラー展開は,

$\left.\rho_{e}\right|_{n+1}=\left.\rho_{e}\right|_{n}+\Delta t \frac{\left.\partial \rho_{e}\right|_{n}}{\partial t}+\frac{\Delta t^{2}}{2} \frac{\left.\partial^{2} \rho_{e}\right|_{n}}{\partial t^{2}}+O\left(\Delta t^{3}\right)$

であり，この方法では右辺第3項まで利用する．右辺第2 項には基礎方程式から,

$$
\frac{\left.\partial \rho_{e}\right|_{n}}{\partial t}=-\frac{\partial\left(\left.\left.\rho_{e}\right|_{n} v_{i}\right|_{n}\right)}{\partial x_{i}}+\left.Q_{e}\right|_{n}
$$

を代入し，右辺第3項には，

$\frac{\left.\partial^{2} \rho_{e}\right|_{n}}{\partial t^{2}} \approx-\frac{\partial}{\partial x_{i}}\left\{\left.\left(-\frac{\partial\left(\left.\left.\rho_{e}\right|_{n} v_{i}\right|_{n}\right)}{\partial x_{i}}+\left.Q_{e}\right|_{n}\right) v_{i}\right|_{n}\right\}$

を代入すれば, $\Delta \rho_{e}=\left.\rho_{e}\right|_{n+1}-\left.\rho_{e}\right|_{n}$ としたとき，

$\Delta \rho_{e}+\Delta t\left(\frac{\partial\left(\rho_{e} v_{i}\right)}{\partial x_{i}}-Q_{e}\right)$ 


$$
-\frac{\Delta t^{2}}{2} \frac{\partial}{\partial x_{i}}\left\{\left(\frac{\partial\left(\rho_{e} v_{i}\right)}{\partial x_{i}}-Q_{e}\right) v_{i}\right\}=0
$$

となるので，これをGalerkin法により空間離散化すると， 計算すべき式を得ることができる.

メッシュサイズは $2.2 \times 2.5 \mathrm{~mm}$ (図-6参照)，時間刻み $\Delta t=0.2$ 秒とした（要素数: 13,354, 節点数: 13,694）. なお, 解析メッシュを作る際の都合上, 解析領域の幅が, 若干, 実験のそれと比べて大きいが，実験結果との比較におい て大きな影響はないと考えている. 計算にあたっては, 解析領域のダルシー流速場が必要であるが，これについ ては，間隙率（透水係数）に時間変化がないと仮定して 初期状態に対して実施した定常浸透流解析結果（図-7参 照）を用いた非連成解析と，10,000秒毎に浸食解析の結 果を受けて地盤内の透水係数分布を更新して得られた浸 透流場を用いる弱連成解析の 2 種類を行った. 浸透流解 析では上下の境界に固定水頭を与え，浸食解析では下端 での間隙流体中の細粒土濃度を 0 とした。 なお弱連成解 析では, 今回の実験の範囲では, 透水係数 $k$ と間隙率 $n$ の 関係は，別途行った透水試験から，

$$
k=0.0697 n-0.0267(\mathrm{~m} / \mathrm{s})
$$

で近似できたことから（模型実験と同じ粗粒土密度で, 間隙率で $0.41 \sim 0.44$ の範囲，細粒分含有率で $15 \sim 10 \%$ の範 囲で試験を実施），計算では，土の体積変化がないと仮 定して細粒分含有率から間隙率を求め, これを用いて透 水係数を更新し, 浸透流場を計算した.

浸食速度 $Q_{e}$ につては, Cividini et al. ${ }^{17}$ の動水勾配を心゙

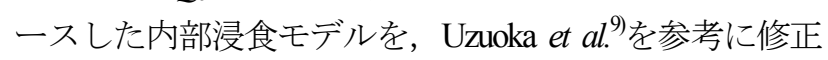
したものを用いた．このモデルにおいては，細粒土の流 出は細粒分含有率の変化として記述されており, 今回実 験に用いたような明らかに粒径が異なる2つの土の混合 土への適用が容易であるため，このモデルを用いた．た だし, 粒径加積曲線が寝ているような, いわゆる粒度が 良い土においては，どの粒径の土に浸食可能性があるの かといった判断が難しく，一律に細粒分含有率で表現で きないと考えられるため, 今回用いたような単純なモデ ルの適用にあたっては, 注意が必要である.

間隙流体に取り込まれた単位体積あたりの細粒土の質 量の変化 $Q_{e}$ は, 細粒分含有率 $f_{c}$ と土粒子密度 $\rho_{s}$ を用いて, 現在の土骨格に含まれる細粒土密度 $\rho$ が

$$
\rho_{f}=(1-n) \rho_{s} f_{c}
$$

と表せるとき，

$$
\begin{aligned}
& Q_{e}=-\frac{\partial \rho_{f}}{\partial t}=-(1-n) \rho_{s} \frac{\partial f_{c}}{\partial t} \\
& \frac{\partial f_{c}}{\partial t}=d_{1}\left(f_{c}-f_{c \infty}\right) i^{d_{2}}
\end{aligned}
$$

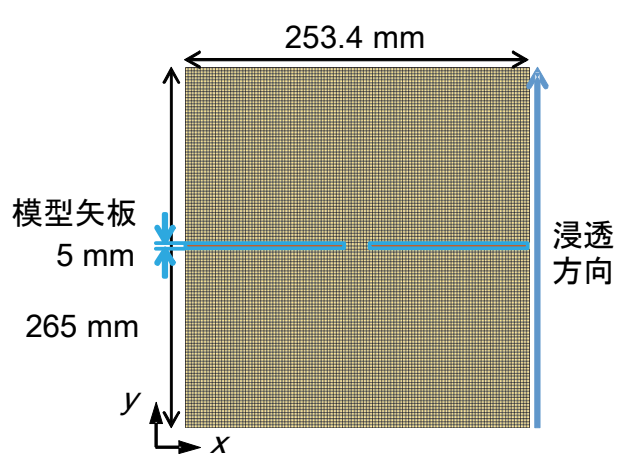

図-6 解析に用いた有限要素メッシュ

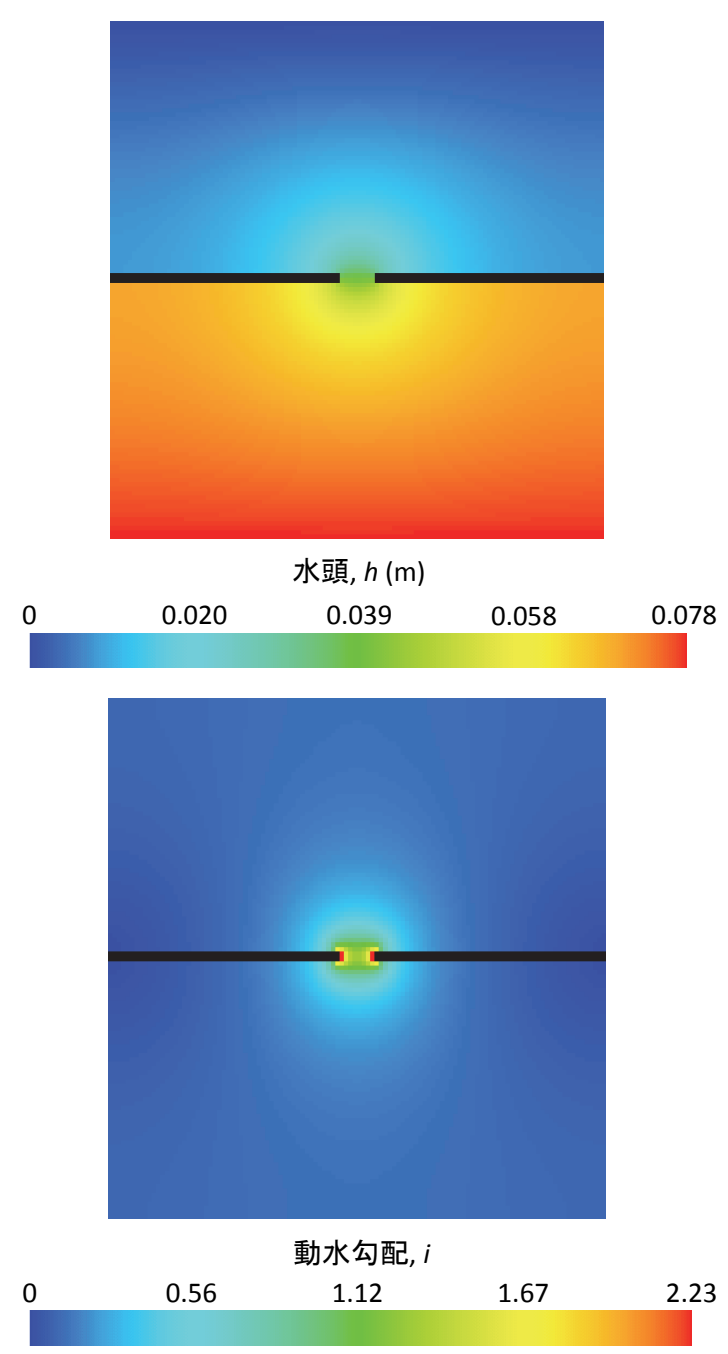

図-7 初期水頭分布（上）と動水勾配分布（下）

$$
f_{c \infty}=f_{c 0}\left\{(1-c) \exp \left(-a \cdot i^{b}\right)+c\right\}
$$

と表せるとした.ここで， $f_{00}=$ 初期細粒分含有率， $i=$ 動 水勾配， $a, b, c, d_{1}, d_{2}$ はフィッティングパラメータである. これらのパラメータは，段階的に供試体に与える動水勾 配を挙げていく上向き 1 次元浸透実験 ${ }^{18}$ に基づいて決定 した（概要は，付録参照）。用いた浸食モデルのパラメ 一夕を表-1に示す. 
表-1 解析に用いた浸食モデルのパラメータ

\begin{tabular}{c||c}
\hline$a$ & 初期細粒分含有率 $=15 \%$ \\
\hline \hline$b$ & 1.1 \\
\hline$c$ & 1.2 \\
\hline$d_{1}$ & 0.67 \\
\hline$d_{2}$ & $0.000024(1 / \mathrm{s})$ \\
\hline
\end{tabular}

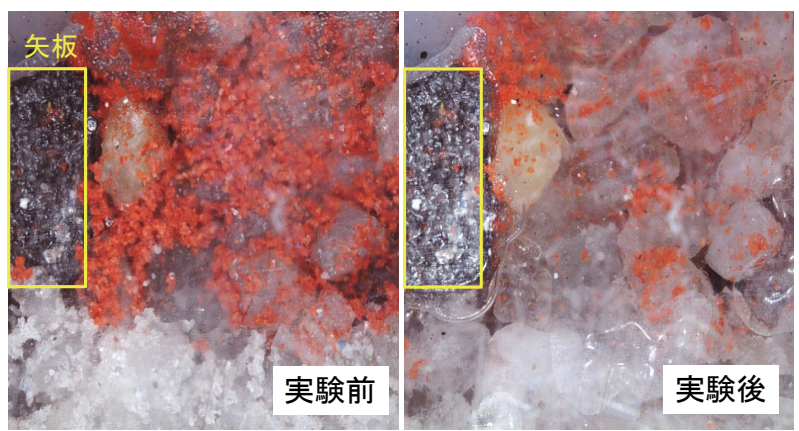

図-8 実験前後の透水孔付近の様子

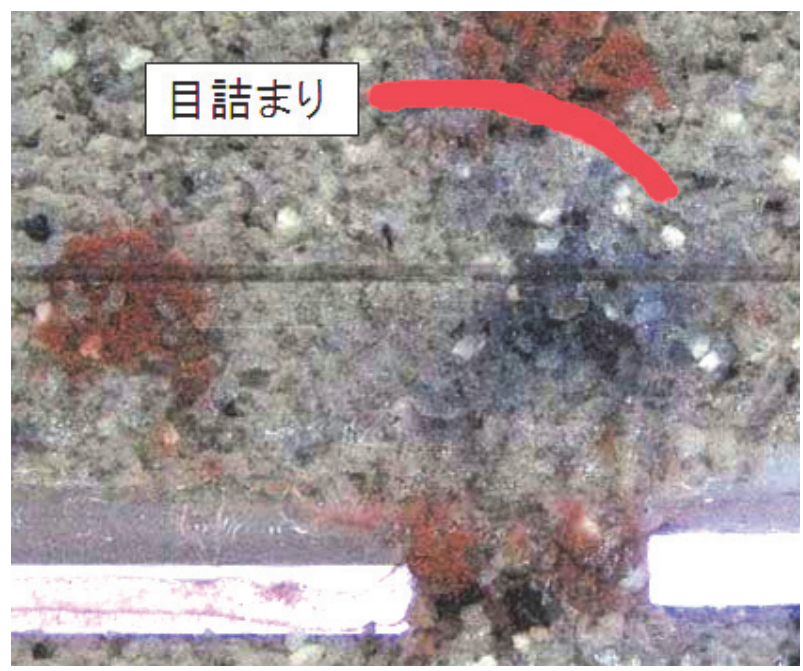

図-9 浸透 18 時間後の細粒土の移動と目詰まり位置

\section{3. 実験 - 解析結果と考察}

\section{（1）実験結果}

図-8に実験前後の透水孔付近の様子を示す。黄色で囲 つた部分が模型矢板で，その右側が透水孔にあたる．模 型地盤作製時に，透水孔内の土には赤色細粒土を，その 上下の土には白色細粒土（無着色細粒土）を細粒分とし て混ぜることによって，細粒土の移動を観察できるよう にした，写真の比較より，浸透流の付与により，細粒土 が流出していることがはっきり確認できる.

図-9に実験における浸透開始18時間後の透水孔付近の 細粒土の移動と目詰まり（初期状態に比べて明らかに細 粒土が増えている状態）の様子を示す。ここでは図中の

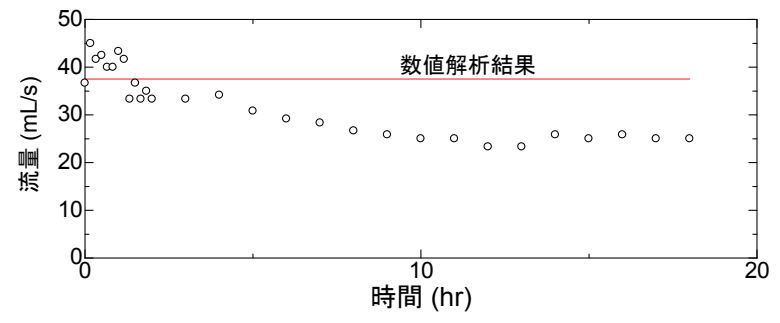

図-10 流量の時間変化

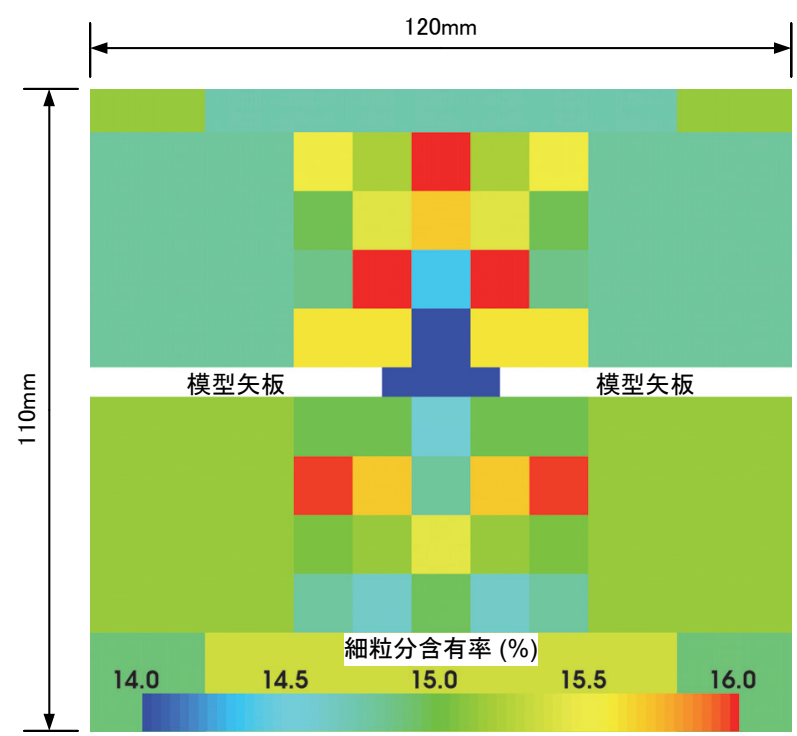

図-11 浸透 18 時間後の細粒分含有率

着色細粒土の初期位置を示していないが，細粒土は浸透 と共に透水孔から離れる方向に移動し，18時間後には， 図の赤線で示寸位置（透水孔より $3 \sim 4 \mathrm{~cm}$ ) に目詰まり が発生していた。

図-10に実験中の流量の変化を示す，併せて，透水係 数が初期から変化しないと仮定した数值解析結果も示し ている. なお流量は，一定時間間隔で（初期は10分，そ の後は1時間おきに）試料上面から浸出した水を，計量 時間を計りながらビーカーで量り取ることによって求め た. 浸透初期には大きな変化は見られず，数值解析結果 と同程度であるが，4時間付近から徐々に流量が低下し， 11時間後には，ほぼ定常状態となっていることが確認で きる.この時の流量は初期の70\%程度であった。上に示 した浸食に伴う細粒土の目詰まりが，このような流量低 下を引き起こしたものと考えられる.

図-11に実験後（浸透開始18時間後）に計測した透水 孔付近の細粒分含有率の分布を示す.これは実験後に各 領域の土を採取し，粒度試験を行うことによって得たも のである. 具体的には，試験後，不飽和状態の試料に薄 板で作られたサンプリング枠を所定の深さまで（10 mm 格子の箇所では $10 \mathrm{~mm}$ ) 貫入した後, 内部の土を掘りだ

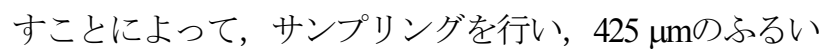
を通ったものを細粒分, 通らなかったものを粗粒分とし 


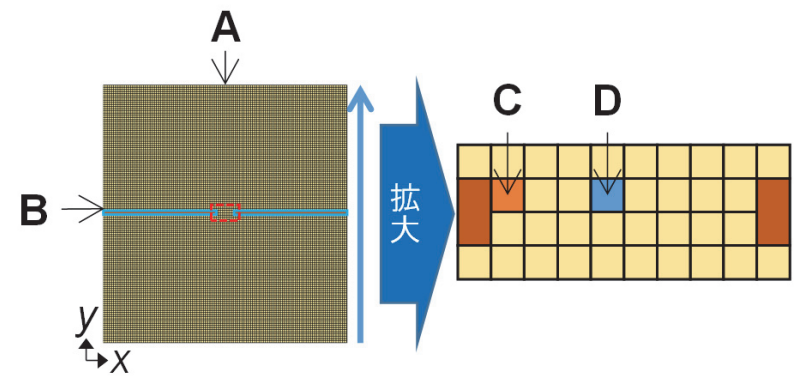

図-12 着目する要素
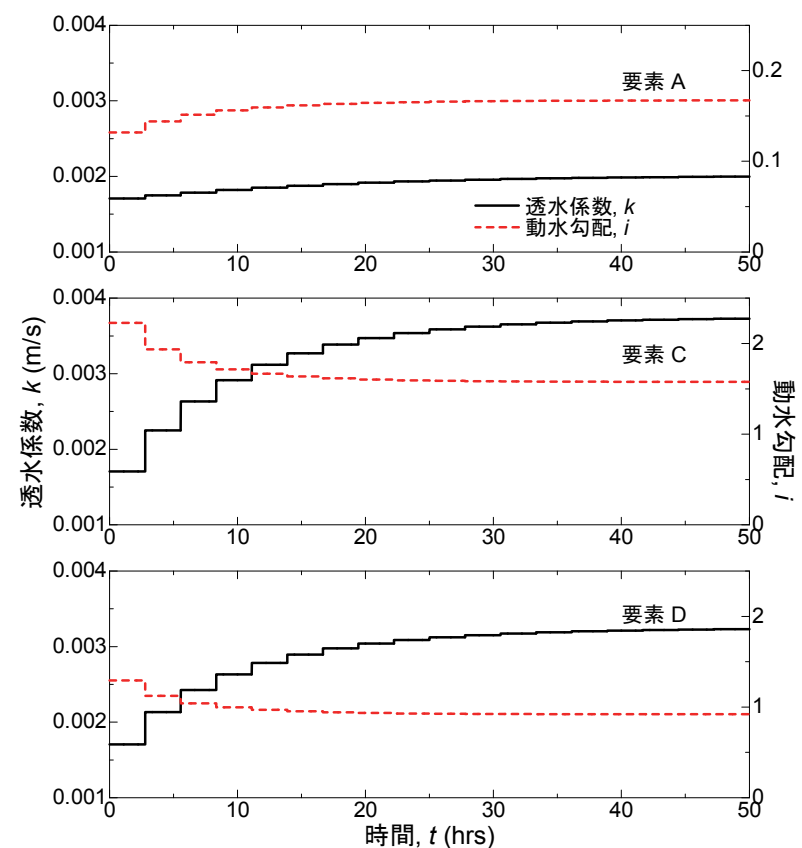

図-13 各要素での透水係数と動水勾配の時間変化

た．なお，透水孔内の細粒分含有率は後に示寸ように約 11\%であるが，図を見やすくするため14\%と同じ色にな っている（青色は14\%以下としてある）。

図を見ると，透水孔近傍では細粒分含有率の低下がみ られ，それを取り囲むように細粒分含有率が大きな領域 が形成されている. また，この領域の形状は，矢板に対 して（透水孔の上下流で）非対称となっている．なお， 図-9と完全に一致している訳ではないが，透水孔上方で 透水孔を取り囲むように形成されている細粒分が増加す る領域と目視で観察された目詰まりが発生していた箇所 は，概ね一致している.

細粒分含有率が上下非対称性になっている原因は明確 ではないが，本来水平浸透流であるものを上向き浸透流 で表現したために，動き出した細粒土が流速の低下によ り下に沈降するなどの重力の影響が表れたことや，浸透 継続時間が十分ではなく，18時間の浸透時間では定常状 態に達していなかった（後に示寸数值解析では, 定常状 態に至るまでに50時間ほど要している）ことなどが，そ
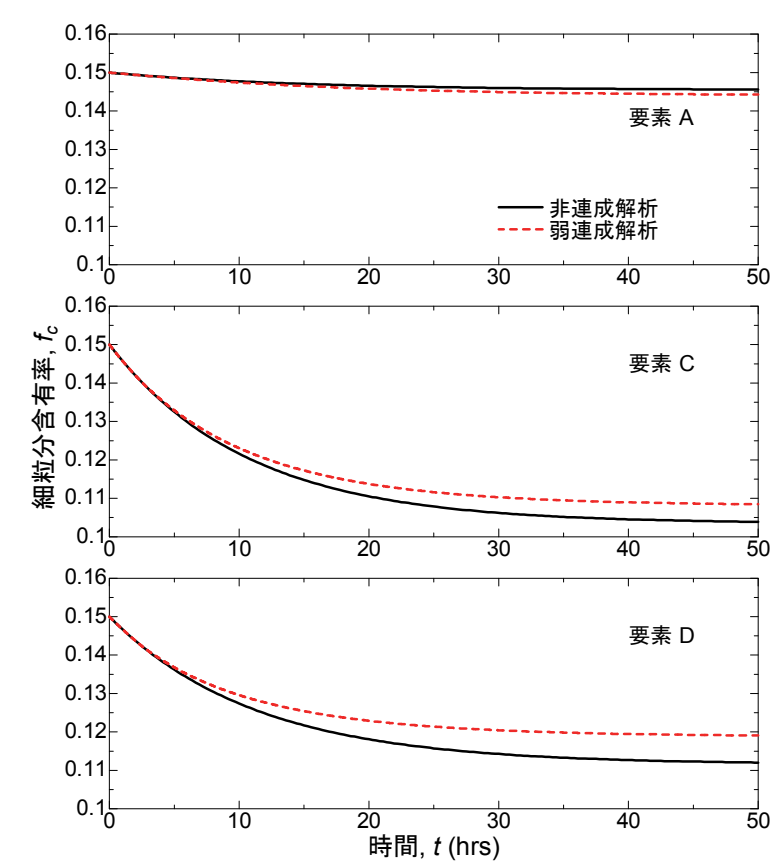

図-14 各要素での細粒分含有率の時間変化

表-2 各要素における 18 時間後の細粒分含有率

\begin{tabular}{c||c|c|c|c}
\hline & $\mathrm{A}$ & $\mathrm{B}$ & $\mathrm{C}$ & $\mathrm{D}$ \\
\hline \hline 模型実験 & $14.6 \%$ & $14.8 \%$ & \multicolumn{2}{|c}{$11.2 \%$} \\
\hline 非連成解析 & $14.7 \%$ & $15.0 \%$ & $11.2 \%$ & $11.9 \%$ \\
\hline 弱連成解析 & $14.6 \%$ & $15.0 \%$ & $11.5 \%$ & $12.4 \%$ \\
\hline
\end{tabular}

の原因として考えられる，なお，今回は同じ実験を2回 実施しているが，サンプリングのための分割領域の大き さが異なるため, 細粒分含有率分布の再現性の確認はで きていない.

\section{（2）解析結果と実験結果との比較}

以下に示寸解析結果では，主に，図-12に示寸透水孔 遠方（要素A）, 透水孔から離れた矢板近傍（要素B） 透水孔内（要素C,D）に着目寸る.

図-13に弱連成解析における各要素での透水係数と動 水勾配の時間変化を示寸，なお，浸透流解析では，節点 での水頭を計算し，アイソパラメトリック要素の積分点 ごとに透水係数を与え，動水勾配を計算しているが，後 に示寸細粒分含有率の変化との対比を容易にするため, ここで示寸值は要素内の平均值とした. 透水孔内（要素 C, D）では, 動水勾配は端部で大きく, 浸食の進展と共 に透水係数 (間隙率) が増加し, 動水勾配が低下してい ることが分かる. 一方, 透水孔から遠く離れた要素Aで は，浸食と共に透水係数が若干低下しているが，透水孔 部での動水勾配低下に伴い, ここでの動水勾配は微増し ている.

図-14に各要素での細粒分含有率の時間変化を示す. 

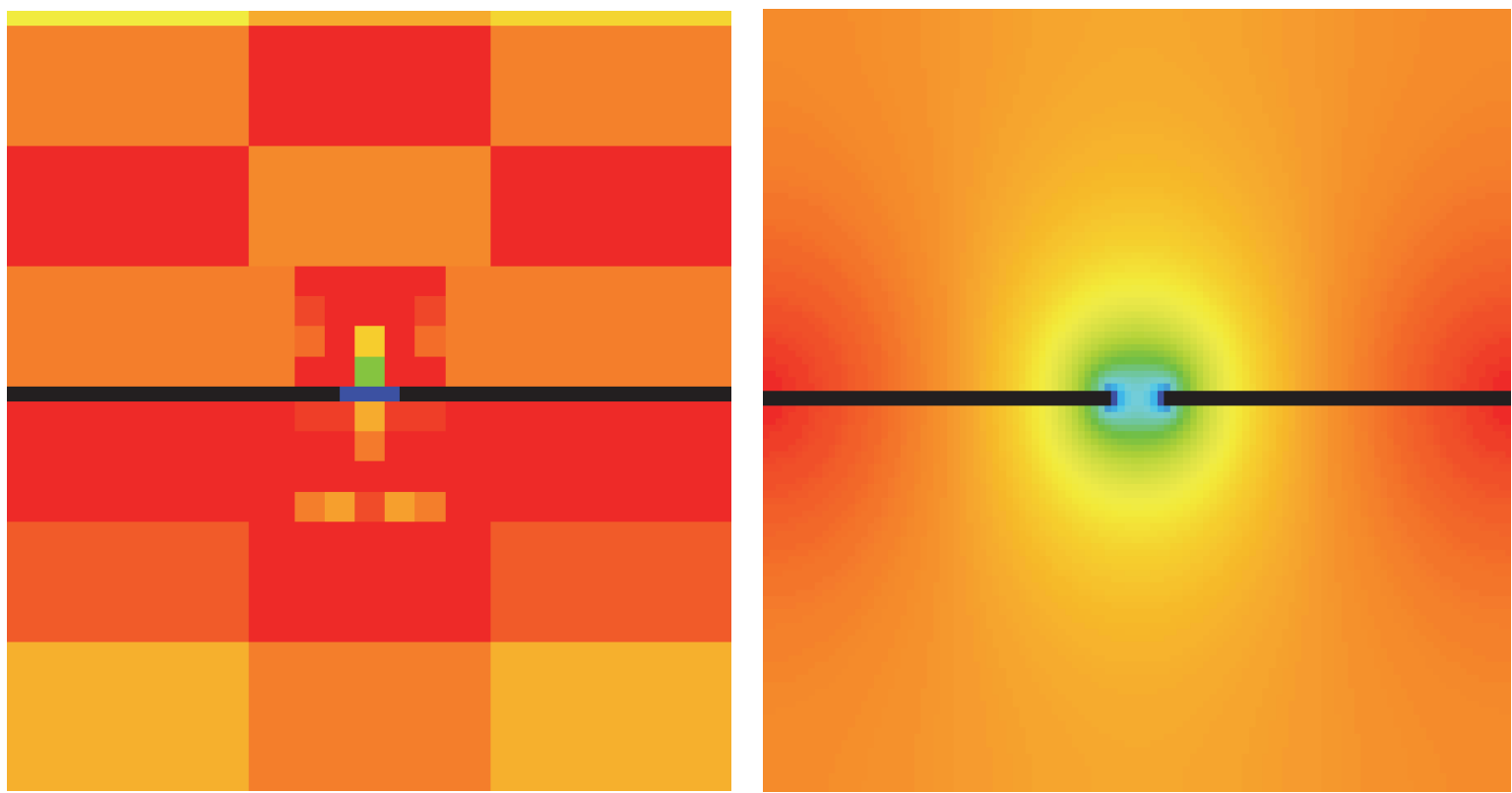

11.1

11.8

12.4

13.1

13.7

14.4

15.0

図-15 18 時間後の細粒分含有率分布（左 : 実験結果，右 : 弱連成解析結果)

浸食解析では，節点で間隙流体中の細粒土濃度を計算し ている，一方，浸食速度については，積分点での細粒土 濃度を求め，これを用いて積分点で計算している．従っ て，細粒分含有率は各積分点で求められているが，実験 との対比を容易にするため, ここで示す值は要素内の平 均值とした. いずれの要素でも細粒分含有率は単調に減 少しており，浸透開始後50時間でほぼ定常状態となって いることが確認できる. 非連成解析と弱連成解析を比べ ると, 弱連成解析結果の方が細粒分の減少割合が小さく なっていることが分かる.これは図-13に示したように， 弱連成解析の場合, 浸食の進展に伴い透水係数が増加し, 透水孔付近での動水勾配が低下することが原因である.

このように，浸食による浸透流場の変化を考慮すると， 浸透流の局所化が緩やかになり，透水孔付近の細粒分流 出量は相対的に小さくなるのに対し, 遠方では, 僅かで はあるが流出量が増加し, 定常状態となる.この結果だ けを見ると，相対的に大きな浸食が発生する箇所では， 浸食と同時に透水係数の増加が生じるため, 急激な拡大 は発生しないことになる，実際には，浸食の進行に伴い， 水の流れが，多孔質体内の浸透流から，パイプ流のよう な局所流が発生する状態に変化することが想定されるが, 今回の解析ではそのような状態は表現されないため,こ のような結果になったと考えられる.

実験を終了した浸透開始から18時間後の各要素におけ る細粒分含有率の比較を表-2に示す. 細粒分含有率の低 下が大きい領域は，数值解析の方が若干大きいものの, 着目した各要素での解析值は，実験とほぼ同等であった。

図-15に実験を終了した浸透開始から18時間後の細粒
分含有率の空間分布を示す.なお，解析では細粒分含有 率は全領域で初期值（15\%）以下になるため，実験では 細粒分が増加している箇所があるものの（図-11参照）, 図を見やすくするため，細粒分含有率が $15 \%$ 超えても， 15\%と同じ色としている（赤色は15\%以上としてある）. いずれも透水孔部で浸食量が最も大きく, そこから離れ るに従って浸食量が低下するという意味では類似してい るが，実験において透水孔より $3 \sim 4 \mathrm{~cm}$ 離れた地点で発 生した目詰まりは，解析では再現できていない，これは， 今回の解析で用いた土の浸食モデルでは一度間隙流体に 取り込まれた細粒土が再び土骨格へ戻ることはなく，動 水勾配の低下による再堆積は表現されていないことによ る. 透水孔部の浸食の程度と言う意味では，今回の数值 解析は実験結果を概ね再現できていると言えるが，その 分布という意味では, 必ずしも良好とは言えない結果と なった．浸食モデルの改善にあたっては，一度間隙流体 に取り込まれた細粒土の低動水勾配時の再堆積について の配慮が必要であろう。

\section{4. 結論}

本研究では，堤防基礎地盤に設置した透水性鋼矢板の 透水孔付近の局所浸透流が引き起こす内部浸食の進展過 程と浸食の程度を明らかにすることを目的として，模型 実験と数值解析を実施した。模型実験では，矢板の透水 孔付近の地盤をモデル化し，これに浸透流を与えること によって，土の浸食過程を観察した．数值解析では，浸 透流によって浸食された細粒土は間隙水に取り込まれ， 
間隙流体としてふるまうと仮定し，その連続条件から得 られる間隙流体中の細粒土濃度に関寸る移流方程式を解 くことによって, 土の浸食過程を計算した.

模型実験によって, 透水孔付近の局所的な浸透流が細 粒土の移動（内部浸食）を発生させることが確認できた. また，浸食に伴う透水孔近傍地盤の細粒分含有率の変化 を調べたところ, 矢板より下流側では透水孔から離れる 方向に細粒土は移動し，透水孔近傍では細粒分含有率の 低下が見られ，それを取り囲むように細粒分含有率が大 きな領域（目詰まり領域）が形成されていることが確認 された. これに伴い, 浸透流量は時間とともに低下し, 実験を終了した浸透から18時間後には，ほぼ定常となっ た.この時の流量は, 初期の70\%程度であった。

数值解析と模型実験との比較から, 比較的簡便な数值 解析ではあるが，細粒分含有率の低下が大きい領域は， 数值解析の方が若干大きいものの, 透水孔付近での細粒 土の流出を概再現できたといえる．ただし，いずれも 透水孔部で浸食量が最も大きく, そこから離れるに従っ て浸食量が低下寸るという意味では類似しているが，実 験において透水孔より $3 \sim 4 \mathrm{~cm}$ 離れた地点で発生した目 詰まりは，解析では再現できていない。これは，今回の 解析で用いた土の浸食モデルでは一度間隙流体に取り込 まれた細粒土が再び土骨格へ戻ることはなく，動水勾配 の低下による再堆積は表現されていないためである。今 回の数值解析では, 最大浸食量（透水孔での細粒分含有 率）と言う意味では，実験結果を概ね再現できていると 言えるが，その分布という意味では，必ずしも良好とは 言えない結果となった．浸食モデルの改善にあたっては, 一度間隙流体に取り込まれた細粒土の低動水勾配時の再 堆積についての配慮が必要であろう。

謝辞 : 本研究の一部は，新日鐵住金（株）からの支援を 受けて実施したものである.

\section{付録}

模型実験で用いた珪砂3号と8号の混合土に対する内部 浸食モデルのフィッティングパラメータを決定するため, 上向き1次元浸透試験を実施した ${ }^{18)}$. ここではその概要 と内部浸食モデルのパラメータ推定の概要を示寸.

システムの概念図と供試体寸法を図-A1に示す．動水 勾配のコントロールは，供試体の上面側の水位を $5 \mathrm{~mm} に$ 固定し, 給水側のタンクの高さを調整することでおこな った. 動水勾配は，0.126から24時間毎に段階的に増加さ せている. なお，最終ステップである6段階目の動水勾 配は, 給水タンクとカラムをつなぐチューブの径が細く, その部分で水頭損失が大きくなってしまったこと，この 時の供試体中の細粒土はすでにある程度流出していたた

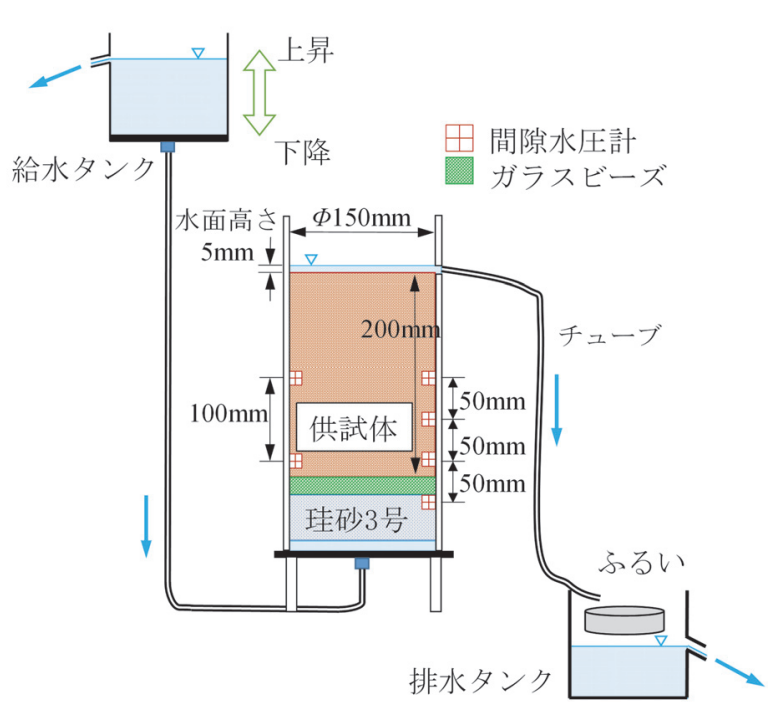

図-A1 上向き 1 次元浸透試験の概要

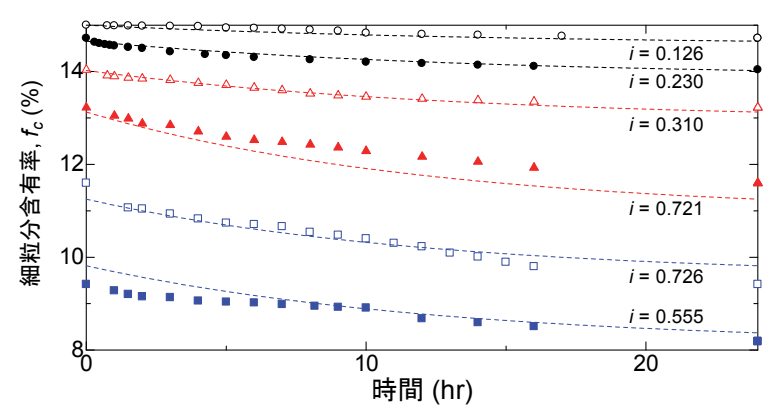

図-A2 各動水勾配での供試体内の細粒分含有率の時間变化

め，供試体の透水性が高くなっていたことなどから，こ の段階での動水勾配が4，5段階目より低いものとなった. 流出した細粒土は，ある時間間隔でその質量を計測した。 このとき, 流水の単位時間当たりの流量もメスシリンダ 一を使用し計測した.

図-A2に実験によって得られた各動水勾配のステップ における供試体内の細粒分含有率の時間変化を示す. 式

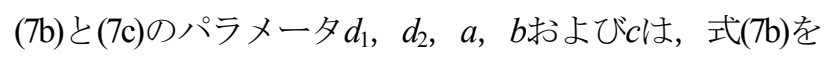
動水勾配一定として積分した式を, 非線形最小二乗法で 図-A2の結果にフィッティングすることで求めた（結果 は表-1参照）。図には，推定パラメータを使った理論值 も破線で示している.

\section{参考文献}

1) 鋼管杭協会: 透水性鋼矢板 技術資料, JASPP 技術ライ ブラリーNo. 108, 23 p., 2004.

2) Ke, L. and Takahashi, A.: Triaxial erosion test for evaluation of mechanical consequences of internal erosion, $\mathrm{Ge}$ otech. Test. J., ASTM, Vol. 37, No. 2, pp. 347-364, 2014.

3) Ke, L. and Takahashi, A.: Experimental investigations on suffusion characteristics and its mechanical consequences on saturated cohesionless soil, Soils Found., Vol. 54, No. 4, pp. 713-730, 2014.

4) Ke, L. and Takahashi, A.: Drained monotonic responses of 
suffusional cohesionless soils, J. Geotech. Geoenviron., ASCE, Vol. 141, No. 8, Paper ID: 04015033, 2015.

5) 佐藤真理: 内部侵食のメカニズムとその定量的評価に 関する研究, 博士論文, 東京大学, 2014.

6) Sterpi, D.: Effects of the erosion and transport of fine particles due to seepage flow, Int. J. Geomech., Vol. 3, No. 1, pp. 111-122, 2003.

7) Cividini, A. and Gioda, G.: Finite-element approach to the erosion and transport of fine particles in granular soils, Int. J. Geomech., Vol. 4, No. 3, pp. 191-198, 2004.

8) Fujisawa, K., Murakami, A. and Nishimura, S.: Numerical analysis of the erosion and the transport of fine particles within soils leading to the piping phenomenon, Soils Found., Vol. 50, No. 4, pp. 471-482, 2010.

9) Uzuoka, R., Ichiyama, T., Mori, T. and Kazama, M.: Hydro-Mechanical analysis of internal erosion with mass exchange between solid and water, Proc 6th Int. Conf. Score and Erosion, Paris, pp. 655-662, 2012.

10) Radzicki, K. and Bonelli, S.: Monitoring of the suffusion process development using thermal analysis performed with IRFTA model, Proc. 6th Int. Conf. Scour and Erosion, Paris, pp. 593-600, 2012.

11) Horikoshi, K. and Takahashi, A.: Suffusion-induced change in spatial; distribution of fine fraction in embankment subjected to seepage flow, Soils Found., Vol. 55, No. 5,pp. 1294-1305, 2015.
12) Kenney T.C. and Lau D. : Internal stability of granular filters. Can. Geotech. J., Vol. 22, No. 2, pp. 215-225, 1985.

13) Li, M. and Fannin, R.J.: Comparison of two criteria for internal stability of granular soil, Can. Geotech. J., Vol. 45, No. 9, pp. 1303-1309, 2008.

14) Wan, C.F. and Fell, R.: Assessing the potential of internal instability and suffusion in embankment dams and their foundations, J. Geotech. Geoenviron. Eng., ASCE, Vol. 134, No. 3, pp. 401-407, 2008.

15) Chang, D.S. and Zhang, L.M.: Extended internal stability criteria for soils under seepage, Soils Found., Vol. 53, No. 4, pp. pp. 569-583, 2013.

16) Donea, J.: A Taylor-Galerkin method for convective transport problems, Int. J. Numer. Meth. Eng., Vol. 20, No. 1, pp. 101-119, 1984.

17) Cividini, A., Bonomi, S., Vignati, G.C. and Gioda, G.: Seepage-induced erosion in granular soil and consequent settlements, Int. J. Geomech., Vol. 9, No. 4, pp. 187-194, 2009.

18) 堀越一輝, 高橋章浩: 浸透流による盛土内の細粒土の 移動に与える再堆積の影響, 地盤工学ジャーナル, Vol. 10, No. 4, pp. 473-488, 2015.

\title{
NUMERICAL AND PHYSICAL MODELLING OF SEEPAGE-INDUCED INTERNAL EROSION AROUND PERMEABLE SHEET PILE
}

\author{
Hibiki KOKAKI, Takahiro MARUYAMA, Kazuki HORIKOSHI, \\ Tomohide TAKEYAMA and Akihiro TAKAHASHI
}

Installation of steel sheet piles at the toe of a levee has been adopted as a countermeasure against liquefaction of the levee foundation in earthquake. Recently, installation of the steel sheet piles at the shoulders of the levee with tying the sheet pile heads by rods is proposed to secure the function of the levee both in earthquake and in overtopping. Since installation of the sheet piles alters the seepage flow in the foundation ground, use of permeable steel sheet piles is also proposed. On the permeable sheet pile, there are holes sufficient to secure the water flow in the ground so that the existence of the sheet pile does not interrupt the seepage flow. However, near the holes, onset and development of internal erosion might occur by the concentrated seepage flow due to the large hydraulic gradient around the holes. In this study, development of internal erosion near the holes on the permeable steel sheet pile is simulated by combining seepage flow analysis and internal erosion analysis. Comparison with physical model test reveals that the experimental result can be captured by the numerical analysis as a whole. However, the clogging of fines in the experiment cannot be modelled, as fines once detached from the soil skeleton cannot be redeposited again with the internal erosion model used in this analysis. 